\title{
SYNTHESIS, CRYSTAL STRUCTURE, AND SPECTRAL AND MAGNETIC PROPERTIES OF CHLORO-BRIDGED CHAIN COMPLEX OF DINUCLEAR RUTHENIUM(II,III) 3,4,5-TRIETHOXYBENZOATE
}

\author{
Hideaki Ishida ${ }^{\mathrm{a}}$, Makoto Handa ${ }^{\mathrm{b} *}$, Ichiro Hiromitsu ${ }^{\mathrm{b}}$, and Masahiro Mikuriya ${ }^{\mathrm{a} *}$ \\ ${ }^{a}$ Department of Chemistry, School of Sciences and Technology, Kwansei Gakuin University, 2-1 Gakuen, Sanda 669-1337, Japan \\ ${ }^{b}$ Department of Material Sciences, Interdisciplinary Faculty of Sciences and Engineering, Shimane University, 1060 Nishikawatsu, \\ Matsue 690-8504, Japan \\ *e-mail: junpei@kwansei.ac.jp, Tel: +81-79-565-8365, Fax: +81-79-565-9077
}

\begin{abstract}
Achloro-bridged chain complex constructed from paddlewheel-type dinuclear ruthenium(II,III) carboxylate units, $\left[\mathrm{Ru}_{2}\left\{3,4,5-\left(\mathrm{C}_{2} \mathrm{H}_{5} \mathrm{O}\right)_{3} \mathrm{C}_{6} \mathrm{H}_{2} \mathrm{CO}_{2}\right\}_{4} \mathrm{Cl}\right]_{n} \cdot 1.2 n \mathrm{C}_{2} \mathrm{H}_{5} \mathrm{OH}\left(\mathbf{1} \cdot 1.2 n \mathrm{C}_{2} \mathrm{H}_{5} \mathrm{OH}\right)$, was synthesized and characterized by elemental analysis and IR and UV-vis spectroscopies. The single-crystal X-ray analysis showed that the complex forms a zig-zag chain structure, in which the chloro ligands bridge the dinuclear units at the axial positions with the $\mathrm{Ru} 1-\mathrm{Cl}-\mathrm{Ru} 2$ angle of $120.38(7)^{\circ}$. A broad band around $1144 \mathrm{~nm}$ and a band at $475 \mathrm{~nm}$ were observed in the diffused reflectance spectra and ascribed to a $\delta \rightarrow \delta^{*}$ and a $\pi\left(\mathrm{RuO}, \mathrm{Ru}_{2}\right) \rightarrow \pi^{*}\left(\mathrm{Ru}_{2}\right)$ transitions, respectively. Temperaturedependence of magnetic susceptibility showed that the antiferromagnetic interaction between the dinuclear units is weak $\left(z J=-0.8 \mathrm{~cm}^{-1}\right)$ with $D$ value of $60 \mathrm{~cm}^{-1}$.
\end{abstract}

Keywords: dinuclear ruthenium(II,III) carboxylate; magnetic property; chloro-bridged complex; polymeric complex.

\section{Introduction}

There have been considerable interests in the coordination chemistry of paddlewheel-type dinuclear ruthenium(II,III) carboxylates $\left[\mathrm{Ru}_{2}\left(\mathrm{O}_{2} \mathrm{CR}\right)^{4}\right]^{+}$, which are paramagnetic with three unpaired electrons on the $\pi^{* 2} \delta^{* 1}$ orbitals in the metal-metal bonds and with large zero-field splitting (ZFS) [1-4]. It is known that dinuclear ruthenium carboxylates form one-dimensional polymeric compounds with some bidentate bridging ligands L, $\left[\mathrm{Ru}_{2}\left(\mathrm{O}_{2} \mathrm{CR}\right)_{4} \mathrm{~L}\right]_{n} \mathrm{X}_{n}(\mathrm{X}=$ =monoanion). We found that magnetic interaction between the dinuclear units is antiferromagnetic and the strength of the interaction depends on the bridging ligand L $[5,6]$. Recently, we reported magnetic properties of polymeric compounds of ruthenium(II,III) 3,4,5-trioctanoxybenzoates, $\left[\mathrm{Ru}_{2}\left\{3,4,5-\left(\mathrm{C}_{8} \mathrm{H}_{17} \mathrm{O}\right)_{3} \mathrm{C}_{6} \mathrm{H}_{2} \mathrm{CO}_{2}\right\}_{4} \mathrm{Y}\right]_{n}\left(\mathrm{Y}=\mathrm{Cl}^{-}, \mathrm{OCN}^{-}\right)$with liquid crystalline properties [7]. However, their structures have never been elucidated by $\mathrm{X}$-ray crystal structure analysis because of their liquid-crystalline properties themselves. In this study, we prepared a chain complexes of ruthenium(II,III) 3,4,5-triethoxybenzoate with chloro bridging ligand, $\left[\mathrm{Ru}_{2}\left\{3,4,5-\left(\mathrm{C}_{2} \mathrm{H}_{5} \mathrm{O}\right)_{3} \mathrm{C}_{6} \mathrm{H}_{2} \mathrm{CO}_{2}\right\}_{4} \mathrm{Cl}\right]_{n} \cdot 1.2 n \mathrm{C}_{2} \mathrm{H}_{5} \mathrm{OH}\left(\mathbf{1} \cdot 1.2 n \mathrm{C}_{2} \mathrm{H}_{5} \mathrm{OH}\right)$ in the hope of obtaining single-crystals suitable for $\mathrm{X}$-ray structure analysis.

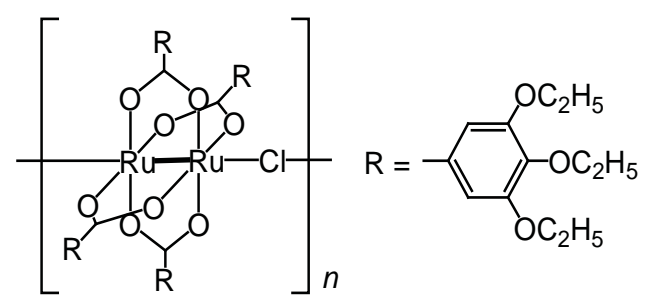

Scheme 1. $\left[\mathrm{Ru}_{2}\left\{3,4,5-\left(\mathrm{C}_{2} \mathrm{H}_{5} \mathrm{O}\right)_{3} \mathrm{C}_{6} \mathrm{H}_{2} \mathrm{CO}_{2}\right\}_{4} \mathrm{Cl}\right]_{n}$.

The obtained complex was characterized by elemental analysis and IR and UV-vis spectra, and temperature dependence of magnetic susceptibilities. The X-ray crystal structure analysis was performed for this complex.

\section{Results and Discussion}

Crystals of a chloro-bridged polymeric complex of dinuclear ruthenium(II,III) 3,4,5-triethoxybenzoate, $\left[\mathrm{Ru}_{2}\left\{3,4,5-\left(\mathrm{C}_{2} \mathrm{H}_{5} \mathrm{O}\right)_{3} \mathrm{C}_{6} \mathrm{H}_{2} \mathrm{CO}_{2}\right\}_{4} \mathrm{Cl}\right]_{n} \cdot 1.2 n \mathrm{C}_{2} \mathrm{H}_{5} \mathrm{OH}\left(\mathbf{1} \cdot 1 \cdot 2 n \mathrm{C}_{2} \mathrm{H}_{5} \mathrm{OH}\right)$, were formed from a reaction of a precursor complex, $\left[\mathrm{Ru}_{2}\left(\mathrm{O}_{2} \mathrm{CC}_{2} \mathrm{H}_{5}\right)_{4} \mathrm{Cl}\right]_{n}$, and 3,4,5-triethoxybenzoic acid in ethanol. The formation of the mixed-valence dinuclear ruthenium(II,III) $3,4,5$-triethoxybenzoate with a metal-metal bond was confirmed by the infrared and electronic spectra, and single-crystal X-ray structure analysis. 


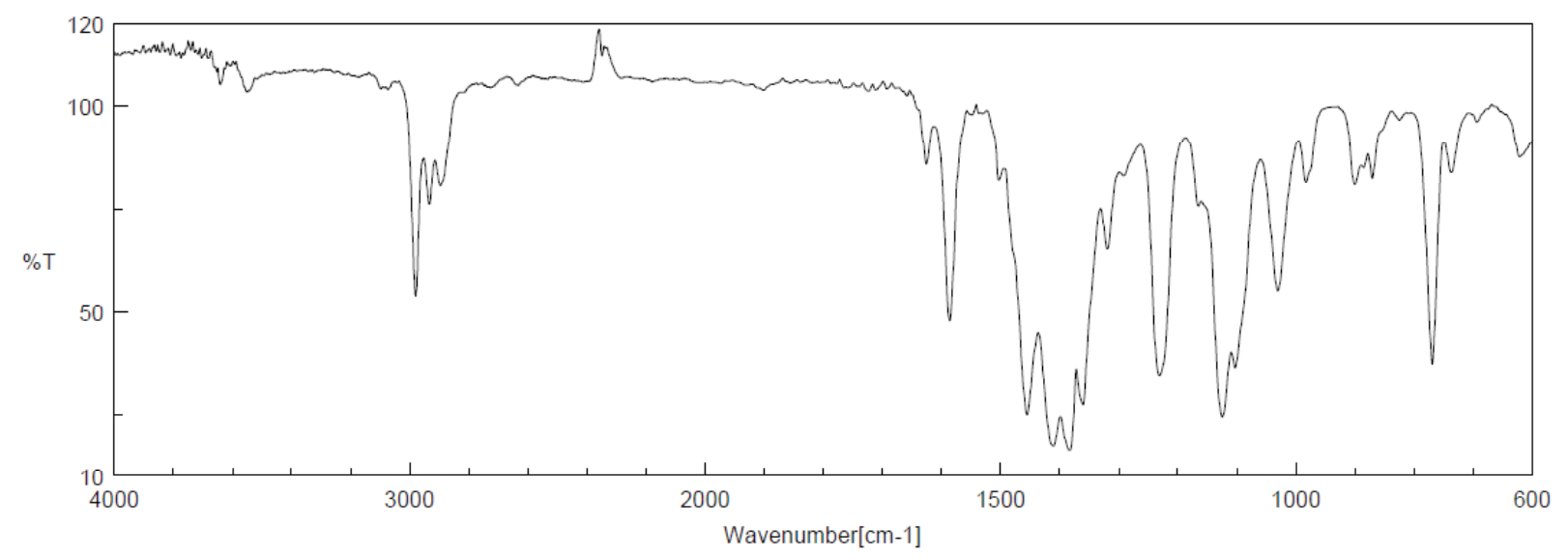

Figure 1. Infrared spectra of $\left[\mathrm{Ru}_{2}\left\{3,4,5-\left(\mathrm{C}_{2} \mathrm{H}_{5} \mathrm{O}\right)_{3} \mathrm{C}_{6} \mathrm{H}_{2} \mathrm{CO}_{2}\right\}_{4} \mathrm{Cl}_{n} \cdot 1 \cdot 1.2 n \mathrm{C}_{2} \mathrm{H}_{5} \mathrm{OH}\left(1 \cdot 1.2 n \mathrm{C}_{2} \mathrm{H}_{5} \mathrm{OH}\right)\right.$.

In the infrared spectrum, two strong bands at 1455 and $1383 \mathrm{~cm}^{-1}$ assignable to asymmetrical and symmetrical stretching vibrations of the carboxyl groups, respectively (Fig. 1). The strong bands at 1411 and $1360 \mathrm{~cm}^{-1} \mathrm{may} \mathrm{be}$ attributed to $\delta\left(\mathrm{CH}_{2}\right)$ and $\delta_{\mathrm{s}}\left(\mathrm{CH}_{3}\right)$ in the ethoxy groups, respectively. The stretching vibrations of aromatic ring were observed at 1586 and $1503 \mathrm{~cm}^{-1}$, and a weak band of $v(\mathrm{Ar}-\mathrm{H})$ at $3074 \mathrm{~cm}^{-1}$. Moreover, stretching modes at 3642 and $3550 \mathrm{~cm}^{-1}$ and bending mode at $1626 \mathrm{~cm}^{-1}$ due to the hydroxyl groups of ethanol molecules were observed. A thermogravimetric analysis showed that $\mathbf{1} \cdot 1.2 n \mathrm{C}_{2} \mathrm{H}_{5} \mathrm{OH}$ releases the ethanol molecules from room temperature to ca. $75{ }^{\circ} \mathrm{C}$ and decomposes from ca. $300{ }^{\circ} \mathrm{C}$ (Fig. 2). These results suggest that the ethanol molecules in the crystals of $\mathbf{1} \cdot 1.2 n \mathrm{C}_{2} \mathrm{H}_{5} \mathrm{OH}$ are lost at room temperature.

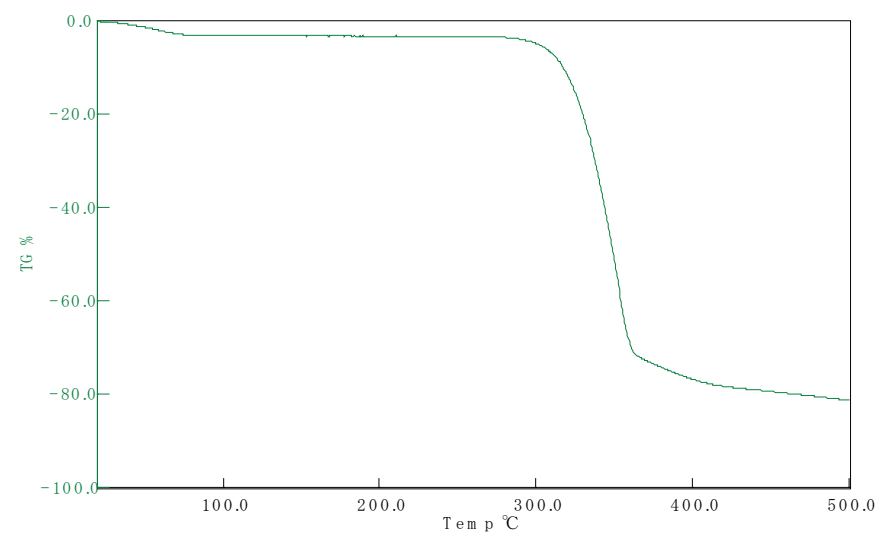

Figure 2. Thermogravimetric analysis of $\left[\mathrm{Ru}_{2}\left\{3,4,5-\left(\mathrm{C}_{2} \mathrm{H}_{5} \mathrm{O}\right)_{3} \mathrm{C}_{6} \mathrm{H}_{2} \mathrm{CO}_{2}\right\}_{4} \mathrm{Cl}_{n} \cdot 1.2 n \mathrm{C}_{2} \mathrm{H}_{5} \mathrm{OH}\left(1 \cdot 1.2 n \mathrm{C}_{2} \mathrm{H}_{5} \mathrm{OH}\right)\right.$.

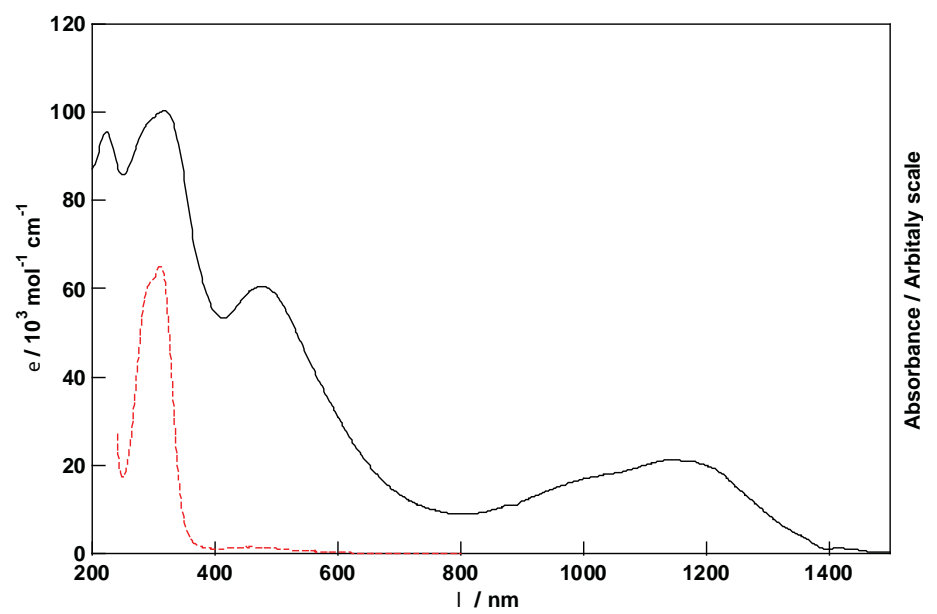

Figure 3. Electronic spectra of $\left[R u_{2}\left\{3,4,5-\left(\mathrm{C}_{2} \mathrm{H}_{5} \mathrm{O}\right)_{3} \mathrm{C}_{6} \mathrm{H}_{2} \mathrm{CO}_{2}\right\}_{4} \mathrm{Cl}\right]_{n} \cdot 1.2 n \mathrm{C}_{2} \mathrm{H}_{5} \mathrm{OH}\left(1 \cdot 1.2 n \mathrm{C}_{2} \mathrm{H}_{5} \mathrm{OH}\right)$ in solid (solid line) and $\mathrm{CH}_{2} \mathrm{Cl}_{2}$ (dashed line). 
The electronic spectra of $\mathbf{1} \cdot 1.2 n \mathrm{C}_{2} \mathrm{H}_{5} \mathrm{OH}$ are shown in Fig. 3. The paddlewheel-type dinuclear structure of $\mathbf{1}$ can be considered to be maintained in $\mathrm{CH}_{2} \mathrm{Cl}_{2}$ solution, because the spectrum in the solution is similar to that in solid. A weak broad absorption band around $1144 \mathrm{~nm}$ in solid is typical for ruthenium(II,III) carboxylates and can be attributed to a $\delta \rightarrow \delta^{*}$ transition within ruthenium(II,III) dinuclear core [8]. A medium band at $475 \mathrm{~nm}$ may be due to $\pi(\mathrm{RuO}$, $\left.\mathrm{Ru}_{2}\right) \rightarrow \pi^{*}\left(\mathrm{Ru}_{2}\right)$ transition $[9,10]$.

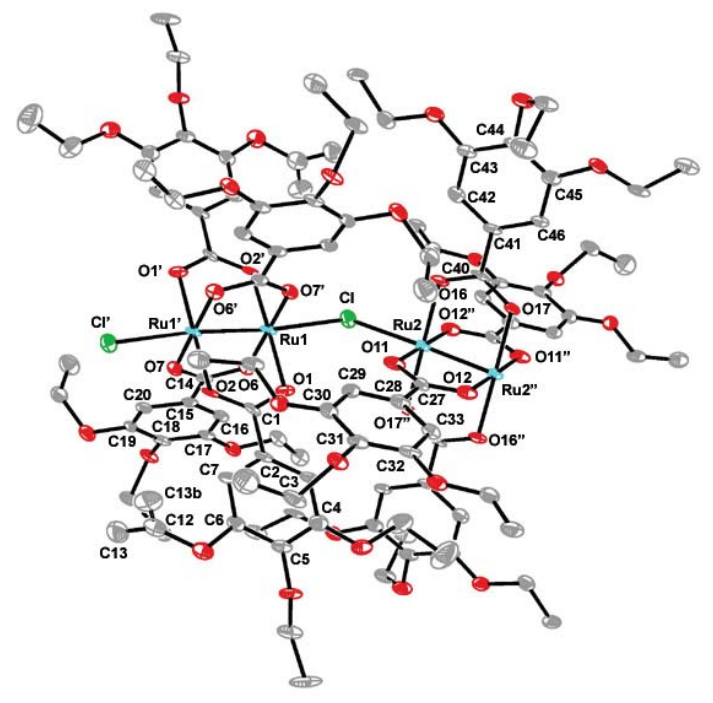

Figure 4. ORTEP drawing of the structure of $\left[\mathrm{Ru}_{2}\left\{3,4,5-\left(\mathrm{C}_{2} \mathrm{H}_{5} \mathrm{O}\right)_{3} \mathrm{C}_{6} \mathrm{H}_{2} \mathrm{CO}_{2}\right\}_{4} \mathrm{Cl}\right]_{n} \cdot 1.2 n \mathrm{C}_{2} \mathrm{H}_{5} \mathrm{OH}$

$\left(1 \cdot 1.2 \mathrm{nC}_{2} \mathrm{H}_{5} \mathrm{OH}\right)$ showing the $50 \%$ probability thermal ellipsoids. Hydrogen atoms and ethanol molecules are omitted for clarity. Symmetry codes: prime: $3-x, 2-y,-1-z$; double prime: $4-x, 2-y,-1-z$.

Selected bond distances $(\AA)$ and angles $\left(^{\circ}\right)$ with esds in parentheses for

Table 1 $\left[\mathrm{Ru}_{2}\left\{3,4,5-\left(\mathrm{C}_{2} \mathrm{H}_{5} \mathrm{O}\right)_{3} \mathrm{C}_{6} \mathrm{H}_{2} \mathrm{CO}_{2}\right\}_{4} \mathrm{Cl}_{n} \cdot 1 \cdot 2 \mathrm{nC}_{2} \mathrm{H}_{5} \mathrm{OH}\left(1 \cdot 1.2 n \mathrm{C}_{2} \mathrm{H}_{5} \mathrm{OH}\right)\right.$.

\begin{tabular}{|c|c|c|c|}
\hline Ru1-Ru1 ${ }^{\mathrm{i}}$ & $2.2907(12)$ & Ru2-Ru2 $2^{\mathrm{ii}}$ & $2.2922(11)$ \\
\hline $\mathrm{Ru} 1-\mathrm{Cl}$ & $2.5580(19)$ & $\mathrm{Ru} 2-\mathrm{Cl}$ & $2.5748(17)$ \\
\hline Ru1-O1 & $2.040(4)$ & Ru2-O11 & $2.038(4)$ \\
\hline $\mathrm{Ru} 1-\mathrm{O} 2^{\mathrm{i}}$ & $2.029(4)$ & $\mathrm{Ru} 2-\mathrm{O} 12^{\mathrm{ii}}$ & $2.037(4)$ \\
\hline Ru1-O6 & $2.026(4)$ & Ru2-O16 & $2.045(4)$ \\
\hline $\mathrm{Ru} 1-\mathrm{O} 7^{\mathrm{i}}$ & $2.013(4)$ & $\mathrm{Ru} 2-\mathrm{O} 17^{\mathrm{ii}}$ & $2.024(4)$ \\
\hline $\mathrm{Ru} 1^{\mathrm{i}}-\mathrm{Ru} 1-\mathrm{Cl}$ & $174.04(5)$ & $\mathrm{Ru} 2^{\mathrm{ii}}-\mathrm{Ru} 2-\mathrm{Cl}$ & $170.70(5)$ \\
\hline 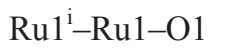 & $90.64(14)$ & $\mathrm{Ru} 2^{\mathrm{ii}}-\mathrm{Ru} 2-\mathrm{O} 11$ & $90.35(13)$ \\
\hline $\mathrm{Ru} 1^{\mathrm{i}}-\mathrm{Ru} 1-\mathrm{O} 2^{\mathrm{i}}$ & $88.26(13)$ & $\mathrm{Ru} 2^{\mathrm{ii}}-\mathrm{Ru} 2-\mathrm{O} 12^{\mathrm{ii}}$ & $88.54(13)$ \\
\hline Ru1 ${ }^{\mathrm{i}-\mathrm{Ru} 1-\mathrm{O} 6}$ & $89.47(13)$ & $\mathrm{Ru} 2^{\mathrm{ii}}-\mathrm{Ru} 2-\mathrm{O} 16$ & $90.13(12)$ \\
\hline $\mathrm{Ru} 1^{\mathrm{i}}-\mathrm{Ru} 1-\mathrm{O} 7^{\mathrm{i}}$ & $89.35(13)$ & 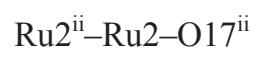 & $88.91(12)$ \\
\hline Cl-Ru1-O1 & $95.06(14)$ & $\mathrm{Cl}-\mathrm{Ru} 2-\mathrm{O} 11$ & $97.70(14)$ \\
\hline $\mathrm{Cl}-\mathrm{Ru} 1-\mathrm{O} 2^{\mathrm{i}}$ & $86.05(13)$ & $\mathrm{Cl}-\mathrm{Ru} 2-\mathrm{O} 12^{\mathrm{ii}}$ & $83.44(13)$ \\
\hline Cl-Ru1-O6 & $92.29(14)$ & $\mathrm{Cl}-\mathrm{Ru} 2-\mathrm{O} 16$ & $94.66(12)$ \\
\hline $\mathrm{Cl}-\mathrm{Ru} 1-\mathrm{O} 7^{\mathrm{i}}$ & $88.97(13)$ & $\mathrm{Cl}-\mathrm{Ru} 2-\mathrm{O} 17^{\mathrm{ii}}$ & $86.45(12)$ \\
\hline $\mathrm{O} 1-\mathrm{Ru} 1-\mathrm{O} 2^{\mathrm{i}}$ & $178.80(19)$ & $\mathrm{O} 11-\mathrm{Ru} 2-\mathrm{O} 12^{\mathrm{ii}}$ & $178.81(18)$ \\
\hline O1-Ru1-O6 & $89.50(17)$ & O11-Ru2-O16 & $88.86(18)$ \\
\hline $\mathrm{O} 1-\mathrm{Ru} 1-\mathrm{O}^{\mathrm{i}}$ & $89.58(16)$ & $\mathrm{O} 11-\mathrm{Ru} 2-\mathrm{O} 17^{\mathrm{ii}}$ & $90.03(18)$ \\
\hline $\mathrm{O} 2^{\mathrm{i}}-\mathrm{Ru} 1-\mathrm{O} 6$ & $90.00(17)$ & $\mathrm{O} 12^{\mathrm{ii}}-\mathrm{Ru} 2-\mathrm{O} 16$ & $90.70(18)$ \\
\hline $\mathrm{O} 2^{\mathrm{i}}-\mathrm{Ru} 1-\mathrm{O} 7^{\mathrm{i}}$ & $90.90(17)$ & 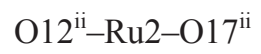 & $90.39(18)$ \\
\hline O6-Ru1-O $7^{\mathrm{i}}$ & $178.50(19)$ & $\mathrm{O} 16-\mathrm{Ru} 2-\mathrm{O} 17^{\mathrm{ii}}$ & $178.52(17)$ \\
\hline $\mathrm{Ru} 1-\mathrm{Cl}-\mathrm{Ru} 2$ & $120.38(7)$ & & \\
\hline
\end{tabular}

Symmetry codes: (i) $3-x, 2-y,-1-z$; (ii) $4-x, 2-y,-1-z$. 
A band at $318 \mathrm{~nm}$ and a shoulder around $289 \mathrm{~nm}$ may be due to transitions within the carboxylato ligand. In $\mathrm{CH}_{2} \mathrm{Cl}_{2}$ solution, large molar absorbance coefficients of the corresponding band at $310 \mathrm{~nm}$ and shoulder around $294 \mathrm{~nm}$ were observed. These are similar to the band at $272 \mathrm{~nm}$ and shoulder around $296 \mathrm{~nm}$ of 3,4,5-triethoxybenzoic acid in $\mathrm{CH}_{2} \mathrm{Cl}_{2}$ solution.

The single-crystal X-ray analysis at $90 \mathrm{~K}$ shows a chain structure of $\mathbf{1} \cdot 1.2 n \mathrm{C}_{2} \mathrm{H}_{5} \mathrm{OH}$, of which the axial positions of the paddlewheel-type dinuclear ruthenium core are occupied by chloro ligands. The ORTEP diagram is shown in Fig. 4 and the selected bond distances and angles are listed in Table 1. There are two crystallographically independent halves of the dinuclear units. Each of the dinuclear units has an inversion centers on the midpoint of the $\mathrm{Ru}-\mathrm{Ru}$ bond.

The chloro ligands bridge the dinuclear units alternately to form a zig-zag chain molecule along $a$-axis. The Ru$\mathrm{Cl}-\mathrm{Ru}$ angle is $\mathbf{1} \cdot 1.2 n \mathrm{C}_{2} \mathrm{H}_{5} \mathrm{OH}\left(120.38(7)^{\circ}\right)$. The $\mathrm{Ru}-\mathrm{Ru}(2.291(1)$ and 2.292(1) $\AA$ ) and $\mathrm{Ru}-\mathrm{Cl}(2.558(2)$ and $2.575(2)$ $\AA$ ) lengths of $\mathbf{1} \cdot 1.2 n \mathrm{C}_{2} \mathrm{H}_{5} \mathrm{OH}$ are normal as this kind of chloro-bridged chain complexes of dinuclear ruthenium(II,III) carboxylates [2]. The $3 \mathrm{D}$ network of $\mathbf{1} \cdot 1.2 n \mathrm{C}_{2} \mathrm{H}_{5} \mathrm{OH}$ is build up by van der Waals interactions and hydrogen bondings, which are $\mathrm{C}-\mathrm{H} \cdots \mathrm{O}$ interactions between the ethoxy groups and $\mathrm{C}-\mathrm{H} \cdots \pi$ interaction between the ethoxy group and the phenyl ring along the $b$-axis, and involve ethanol molecules along the $c$-axis. The hydrogen bonding geometry is shown in Fig. 5 and Table 2.

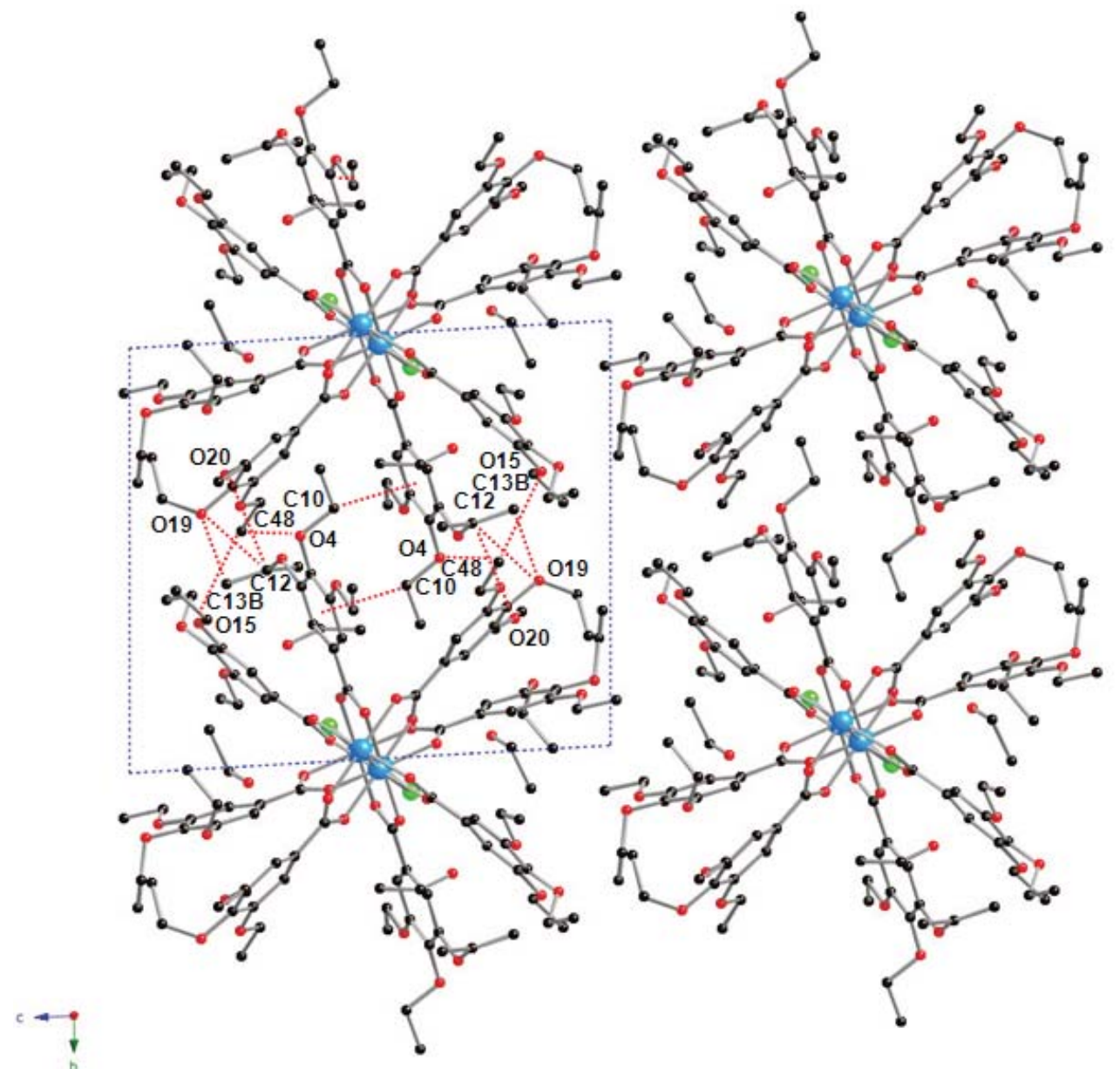

Figure 5. Packing diagram of $\left[\mathrm{Ru}_{2}\left\{3,4,5-\left(\mathrm{C}_{2} \mathrm{H}_{5} \mathrm{O}\right)_{3} \mathrm{C}_{6} \mathrm{H}_{2}^{-} \mathrm{CO}_{2}\right\}_{4} \mathrm{Cl}\right]_{n} \cdot 1.2 n \mathrm{C}_{2} \mathrm{H}_{5} \mathrm{OH}\left(1 \cdot 1.2 n \mathrm{C}_{2} \mathrm{H}_{5} \mathrm{OH}\right)$ along a-axis. Hydrogen atoms are omitted for clarity. Dashed lines show hydrogen-bonds between one chain molecule and the peripheral chains.

Table 2

Hydrogen bond geometry.

\begin{tabular}{|c|c|c|c|c|}
\hline $\mathrm{D}-\mathrm{H} \cdots \mathrm{A}$ & D-H $(\AA)$ & $\mathrm{H} \cdots \mathrm{A}(\AA)$ & $\mathrm{D} \cdots \mathrm{A}(\AA)$ & $\mathrm{D}-\mathrm{H} \cdots \mathrm{A}\left({ }^{\circ}\right)$ \\
\hline $\mathrm{C} 10^{\mathrm{i}}-\mathrm{H} 10 \mathrm{~B}^{\mathrm{i} \cdots} \pi^{[\mathrm{a}]}$ & 0.99 & 2.69 & 3.463 & 135 \\
\hline $\mathrm{C} 12^{\mathrm{ii}}-\mathrm{H} 12 \mathrm{~B}^{\mathrm{ii}} \ldots \mathrm{O} 19$ & 0.99 & 2.65 & $3.549(9)$ & 151 \\
\hline 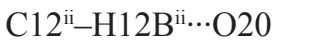 & 0.99 & 2.72 & $3.469(9)$ & 133 \\
\hline 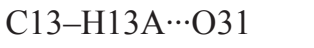 & 0.98 & 2.31 & $2.81(3)$ & 110 \\
\hline C13B ${ }^{\mathrm{ii}}-\mathrm{H} 13 \mathrm{~F}^{\mathrm{ii}} \ldots \mathrm{O} 19$ & 0.98 & 2.69 & $3.12(4)$ & 107 \\
\hline
\end{tabular}




\begin{tabular}{|c|c|c|c|c|}
\hline 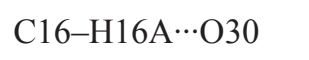 & 0.95 & 2.44 & $3.388(8)$ & 177 \\
\hline 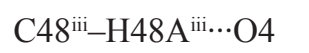 & 0.98 & 2.46 & $3.416(9)$ & 165 \\
\hline $\mathrm{C} 48^{\mathrm{iii}-\mathrm{H} 48 \mathrm{~B}^{\mathrm{iii} . . .} \mathrm{O} 15}$ & 0.98 & 2.63 & $3.412(9)$ & 137 \\
\hline $\mathrm{C} 51^{\mathrm{iv}}-\mathrm{H} 51 \mathrm{~B}^{\mathrm{iv} \cdots \mathrm{O} 30}$ & 0.99 & 2.69 & $3.637(8)$ & 159 \\
\hline C61 ${ }^{\mathrm{v}}-\mathrm{H} 61 \mathrm{C}^{\mathrm{v}} \cdots \mathrm{O} 9$ & 0.98 & 2.74 & $3.582(9)$ & 144 \\
\hline $\mathrm{O} 30-\mathrm{H} 30 \mathrm{~A}^{[\mathrm{b}] \ldots} \mathrm{Cl}$ & 0.84 & $3.53^{[b]}$ & $3.297(5)$ & $67^{[\mathrm{b}]}$ \\
\hline 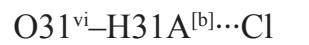 & 0.84 & $3.50^{[\mathrm{b}]}$ & $3.06(3)$ & $53^{[\mathrm{b}]}$ \\
\hline
\end{tabular}

[a] Centroid of phenyl ring with C2, C3, C4, C5, C6, and C7. [b] These hydrogen atoms are incorrectly positioned because it isn't located by D-Fourier synthesis.

Symmetry codes: (i) $3-x, 3-y,-1-z$; (ii) $1+x,-1+y, z$; (iii) $x, 1+y, z$; (iv) $4-x, 2-y,-1-z$; (v) $3-x, 2-y,-z$; (vi) $3-x$, $2-y,-1-z$.

Temperature dependence of the magnetic susceptibilities and effective magnetic moments is shown in Fig. 6.

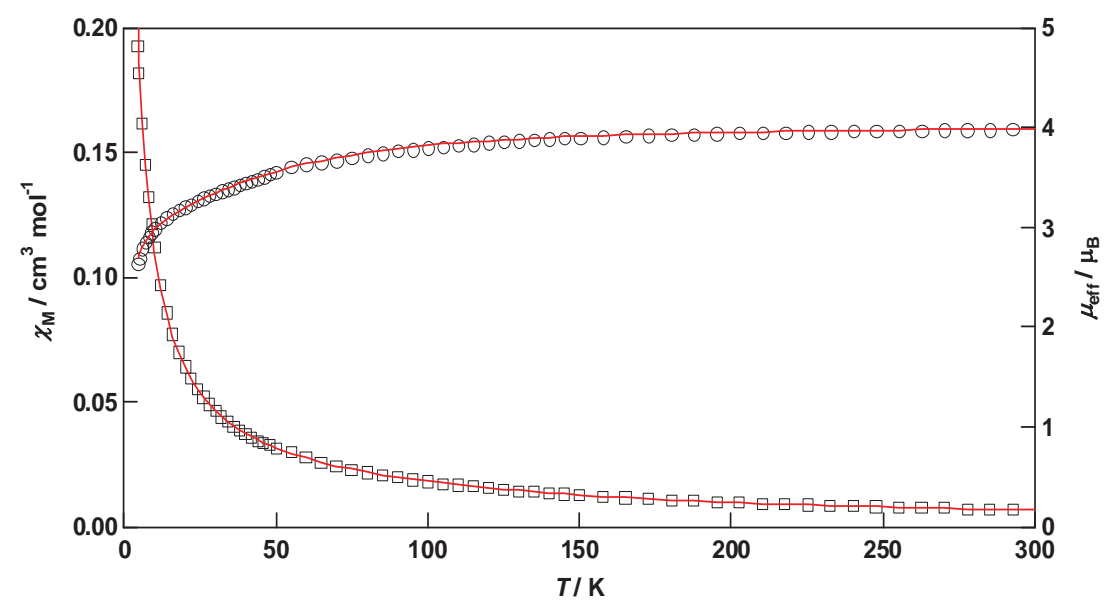

Figure 6. Temperature dependence of magnetic susceptibilities (squares) and effective magnetic moments (circles) of $\left[\mathrm{Ru}_{2}\left\{3,4,5-\left(\mathrm{C}_{2} \mathrm{H}_{5} \mathrm{O}\right)_{3} \mathrm{C}_{6} \mathrm{H}_{2} \mathrm{CO}_{2}\right\}_{4} \mathrm{Cl}\right]_{n} \cdot 1.2 n \mathrm{C}_{2} \mathrm{H}_{5} \mathrm{OH}\left(1 \cdot 1.2 n \mathrm{C}_{2} \mathrm{H}_{5} \mathrm{OH}\right)$.

The magnetic moment of $\mathbf{1} \cdot 1.2 n \mathrm{C}_{2} \mathrm{H}_{5} \mathrm{OH}$ is $3.99 \mu_{\mathrm{B}}$ at $300 \mathrm{~K}$ per dinuclear ruthenium(II,III) unit, which is slightly higher than the spin-only value of $S=3 / 2\left(3.87 \mu_{\mathrm{B}}\right)$. The magnetic moment gradually decreases with lowering of temperature until reaching $2.63 \mu_{\mathrm{B}}$ at $4.5 \mathrm{~K}$, being typical of chain complexes of dinuclear ruthenium(II,III) carboxylates $[2,4]$. The magnetic data were analyzed by a molecular field approximation considering the ZFS effect to estimate the magnitude of the antiferromagnetic interaction [11-13]. This approximation has been commonly applied for dinuclear ruthenium(II,III) carboxylates using the following equations:

$$
\begin{aligned}
& \chi^{\prime}=\chi /\left\{1-\left(2 z J / N g^{2} \mu_{\mathrm{B}}^{2}\right) \chi\right\} \\
& \chi=\left(\chi_{/ /}+2 \chi_{\perp}\right) / 3 \\
& \chi_{/ /}=\left(N g^{2} \mu_{\mathrm{B}}^{2} / k T\right)[1+9 \exp (-2 D / k T)] / 4\{1+\exp (-2 D / k T)\} \\
& \chi_{\perp \perp}=\left(N g^{2} \mu_{\mathrm{B}}^{2} / k T\right)[4+(3 k T / D)\{1-\exp (-2 D / k T)\}] / 4\{1+\exp (-2 D / k T)\}
\end{aligned}
$$

where $z J$ is the exchange integral multiplied by the number of interacting neighbors, $\chi$ is the magnetic susceptibility of the individual dinuclear unit, and $D$ is the ZFS parameter. The $D$ parameter was fixed at $60 \mathrm{~cm}^{-1}$ which is a normal value for dinuclear ruthenium(II,III) carboxylates [2]. The $g$ value was treated as isotropic. Best fitting curve was obtained with the parameters; $z J=-0.8 \mathrm{~cm}^{-1}, g=2.08$. This results show that a weak antiferromagnetic interaction is operating between the dinuclear ruthenium units, being consistent with the small $\mathrm{Ru}-\mathrm{Cl}-\mathrm{Ru}$ angle and the long $\mathrm{Ru}-\mathrm{Cl}$ lengths of $\mathbf{1} \cdot 1.2 n \mathrm{C}_{2} \mathrm{H}_{5} \mathrm{OH}$.

\section{Conclusions}

By using the ethoxy derivative of 3,4,5-trialkoxybenzoate, a chain complex, $\left[\mathrm{Ru}_{2}\left\{3,4,5-\left(\mathrm{C}_{2} \mathrm{H}_{5} \mathrm{O}\right)_{3} \mathrm{C}_{6} \mathrm{H}_{2} \mathrm{CO}_{2}\right\}_{4} \mathrm{Cl}\right]_{n} \cdot 1.2 n \mathrm{C}_{2} \mathrm{H}_{5} \mathrm{OH}$, was successfully isolated as single-crystals which enabled us to determine the crystal structure by X-ray structure analysis. The crystal structure revealed a zig-zag one-dimensional chain with an alternated arrangement of dinuclear ruthenium units and chloro ions. In accordance with the structural feature, a weak antiferromagnetic interaction was observed for the present complex. 


\section{Experimental}

Synthesis: $\left[\mathrm{Ru}_{2}\left(\mathrm{O}_{2} \mathrm{CC}_{2} \mathrm{H}_{5}\right)_{4} \mathrm{Cl}\right]_{n}$ and 3,4,5-triethoxybenzoic acid were prepared by literature methods $[14,15]$. Other reagents and solvents were obtained from commercial sources and were used without further purification.

$\left[\mathrm{Ru}_{2}\left(\mathrm{O}_{2} \mathrm{CC}_{2} \mathrm{H}_{5}\right)_{4} \mathrm{Cl}\right]_{n}(105 \mathrm{mg}, 0.198 \mathrm{mmol})$ and 3,4,5-triethoxybenzoic acid $(500 \mathrm{mg}, 1.966 \mathrm{mmol})$ were refluxed in $5 \mathrm{ml}$ of ethanol for 24 hours. The mixture was left at room temperature to give red-brown crystals. The crystals were filtered, washed with $1 \mathrm{ml}$ of 1 -pentanol and $5 \mathrm{ml}$ of hexane, and dried in air. Yield: $223 \mathrm{mg}$ (84\%). Anal. Found: C, 50.09; H, 6.00\%. Calcd for $\mathrm{C}_{52} \mathrm{H}_{68} \mathrm{ClO}_{20} \mathrm{Ru}_{2} \cdot 1.2 \mathrm{C}_{2} \mathrm{H}_{5} \mathrm{OH}$ : C, 50.03; H, 5.80\%. IR (KBr): $v\left(\mathrm{C}_{2} \mathrm{H}_{5}-\mathrm{OH}\right) 3642,3550$, $v(\mathrm{Ar}-\mathrm{H}) 3074, v_{\mathrm{as}}\left(\mathrm{CH}_{3}\right) 2979, v_{\mathrm{as}}\left(\mathrm{CH}_{2}\right) 2933, v_{\mathrm{s}}\left(\mathrm{CH}_{3}\right)$ 2896, $\delta\left(\mathrm{C}_{2} \mathrm{H}_{5}-\mathrm{OH}\right) 1626, v(\mathrm{Ar}) 1586,1503, v_{\mathrm{as}}\left(\mathrm{CO}_{2}^{-}\right) 1455$, $\delta\left(\mathrm{CH}_{2}\right) 1411, v_{\mathrm{s}}\left(\mathrm{CO}_{2}^{-}\right) 1383, \delta_{\mathrm{s}}\left(\mathrm{CH}_{3}\right) 1360 \mathrm{~cm}^{-1}$. Diffuse reflectance spectrum: $\lambda_{\max } 222,289 \mathrm{sh}, 318,475,1025 \mathrm{sh}, 1144$ nm. UV-vis: $\lambda_{\max }\left(\varepsilon / \mathrm{mol}^{-1} \mathrm{~cm}^{-1}\right.$, in $\left.\mathrm{CH}_{2} \mathrm{Cl}_{2}\right) 294 \mathrm{sh}(61000), 310(65000), 460(1400) \mathrm{nm}$.

Measurements: Thermogravimetric analysis was performed over a range of $20-500{ }^{\circ} \mathrm{C}$ at a heating rate of $10{ }^{\circ} \mathrm{C} / \mathrm{min}$ in a nitrogen flow of $100 \mathrm{ml} / \mathrm{min}$ on a Seiko TG/DTA 220U. Elemental analyses for carbon, hydrogen, and nitrogen were done using a Thermo-Finnigan FLASH EA1112 analyzer. Infrared spectra were measured with a JASCO MFT-2000 FT-IR Spectrometer in the $4000-600 \mathrm{~cm}^{-1}$ region. Electronic spectra were measured with a Shimadzu UVvis-NIR Recording Spectrophotometer (Model UV-3100). Magnetic susceptibilities were measured with a Quantum Design MPMS-5S SQUID susceptometer operating at a magnetic field of $0.5 \mathrm{~T}$ over a range of $4.5-300 \mathrm{~K}$. The susceptibilities were corrected for the diamagnetism of the constituent atoms using Pascal's constants. The effective magnetic moments were calculated from the equation $\mu_{\text {eff }}=2.828 \sqrt{ } \chi_{\mathrm{M}} T$, where $\chi_{\mathrm{M}}$ is the molar magnetic susceptibility per mole of dinuclear ruthenium(II,III) unit.

X-Ray Crystallography: Diffraction data were collected on a Bruker SMART APEX CCD diffractometer using graphite-monochromated Mo Ka radiation at $90 \mathrm{~K}$ and indexed using the SMART software. Crystal data and details concerning data collection are given in Table 3. The cell parameters were refined by full-matrix least-squares on $F^{2}$. Integrated intensity information for each reflections was obtained and corrected using the SAINT+ program package including the reduction program SAINT and the empirical absorption correction program SADABS. The structure was solved using the SHELXTL program. The ruthenium atoms were positioned by a Patterson synthesis, and the residual non-hydrogen atoms were located by D-Fourier synthesis. All of non-hydrogen atoms were refined by full-matrix leastsquares on $F^{2}$ with restrain for the distances between $\mathrm{C} 12$ and $\mathrm{C} 13 \mathrm{~b}$, and between $\mathrm{C} 9$ and $\mathrm{C} 63$. The ethanol molecule constructed from $\mathrm{O} 31, \mathrm{C} 62$, and $\mathrm{C} 63$ was refined with an occupancy rate of 0.208 . The hydrogen atoms were inserted at their ideal positions and fixed there. CCDC 727560 for $\mathbf{1} 1.2 n \mathrm{C}_{2} \mathrm{H}_{5} \mathrm{OH}$ contains supplementary crystallographic data for this paper. These data can be obtained free of charge at www.ccdc.cam.ac.uk/conts/retrieving.html [or from the Cambridge Crystallographic Data Centre, 12 Union Road, Cambridge CB12 1EZ, UK; fax: (internet.) +44-1223/336033; E-mail: deposit@ccdc.cam.ac.uk].

Crystallographic data for $\left[\mathrm{Ru}_{2}\left\{3,4,5-\left(\mathrm{C}_{2} \mathrm{H}_{5} \mathrm{O}\right)_{3} \mathrm{C}_{6} \mathrm{H}_{2} \mathrm{CO}_{2}\right\}_{4} \mathrm{Cl}_{n} \cdot 1.2 n \mathrm{C}_{2} \mathrm{H}_{5} \mathrm{OH}\left(1 \cdot 1.2 n \mathrm{C}_{2} \mathrm{H}_{5} \mathrm{OH}\right)\right.$.

\begin{tabular}{ll}
\hline Formula & $\mathrm{C}_{54.42} \mathrm{H}_{75.25} \mathrm{C}$ \\
Formula weight & 1306.33 \\
Temperature / K & 90 \\
Crystal dimensions / mm & $0.58 \times 0.12 \times$ \\
Crystal system & Triclinic \\
Space group & $\overline{P 1}$ \\
$a / \AA$ & $13.076(4)$ \\
$b / \AA$ & $14.479(4)$ \\
$c / \AA$ & $16.051(4)$ \\
$\alpha / \circ$ & $86.527(5)$ \\
$\beta / \circ$ & $88.824(6)$ \\
$\gamma /{ }^{\circ}$ & $78.889(5)$ \\
$V / \AA^{3}$ & $2976.5(13)$ \\
$Z$ & 2 \\
$d_{\text {calcd. }} / \mathrm{gcm}^{-3}$ & 1.458 \\
$\mu / \mathrm{mm}^{-1}$ & 0.629 \\
$F(000)$ & 1353
\end{tabular}


No. of reflections collected

No. of independent reflections

13112

$\theta$ range $/{ }^{\circ}$

Data / Restraints / Parameters

1.44 to 28.48

Goodness-of-fit on $F^{2}$

$13112 / 2 / 741$

$R_{1}, w R_{2}[I>2 \sigma(I)]^{[\mathrm{a}]}$

0.923

$R_{1}, w R_{2}$ (all data)

$0.0705,0.1562$

$(\Delta / \sigma)_{\max }$

$0.1228,0.1728$

0.001

$(\Delta \rho)_{\max } / \mathrm{e} \AA^{-3}$

2.473

$(\Delta \rho)_{\min } / \mathrm{e} \AA^{-3}$

Diffractometer
$-2.134$

Bruker SMART APEX CCD

$[\mathrm{a}] R_{1}=\Sigma|| F_{\mathrm{o}}|-| F_{\mathrm{c}}|/ \Sigma| F_{\mathrm{o}} \mid ; R_{\mathrm{w}}=\left[\Sigma \omega\left(F_{\mathrm{o}}^{2}-F_{\mathrm{c}}{ }^{2}\right)_{2} / \Sigma \omega\left(F_{\mathrm{o}}{ }^{2}\right)_{2}\right]^{1 / 2}$.

\section{Acknowledgements}

The present work was partially supported by the "Open research Center" Project for private Universities: matching fund subsidy and Grants-in-Aid for Scientific research Nos. 19550074 and 20550066 from the Ministry of Education, Culture, Sports, Science and Technology (Japan).

\section{References}

[1]. Cotton, F. A.; Murillo, C. A.; Walton, R. A. Multiple Bonds between Metal Atoms. 3rd ed. Springer Science and Business Media: New York, 2005.

[2]. Mikuriya, M.; Yoshioka, D.; Handa, M. Coord. Chem. Rev. 2006, 250, 2194-2211.

[3]. Aquino, M. A. S. Coord. Chem. Rev. 2004, 248, 1025-1045.

[4]. Aquino, M. A. S. Coord. Chem. Rev. 1998, 170, 141-202.

[5]. Yoshioka, D.; Mikuriya, M.; Handa, M. Bull. Chem. Soc. Jpn. 2004, 77, 2205-2211.

[6]. Handa, M.; Ishida, H.; Ito, K.; Adachi, T.; Ikeue, T.; Hiromitsu, I.; Mikuriya, M.; Kasuga, K. Chem. Papers, 2008, 62, 410-416.

[7]. Ishida, H.; Handa, M.; Hiromitsu, I.; Ujiie, S.; Mikuriya, M. Achievements in Coordination, Bioinorganic and Applied Inorganic Chemistry. ed. by Melnik, M.; Sima, J.; Tatarko, M. Slovak Technical University Press: Bratislava, 2007; pp 121-127.

[8]. Miskowski, V. M.; Loehr, T. M.; Gray, H. B. Inorg. Chem. 1987, 26, 1098-1108.

[9]. Norman, G. J.; Renzoni, G. E.; Case, D. A. J. Am. Chem. Soc. 1979, 101, 5256-5267.

[10]. Miskowski, V. M.; Gray, H. B. Inorg. Chem. 1988, 27, 2501-2506.

[11]. Telser, J.; Drago, R. S. Inorg. Chem. 1984, 23, 3114-3120.

[12]. Telser, J.; Drago, R. S. Inorg. Chem. 1985, 24, 4765.

[13]. O’Connor, C. J. Prog. Inorg. Chem. 1982, 29, 203-283.

[14]. Stephenson, T. A.; Wilkinson, G. J. Inorg. Nucl. Chem. 1966, 28, 2285-2291.

[15]. Terazzi, E.; Torelli, S.; Bernardinelli, G.; Rivera, J.-P.; Bénech, J.-M.; Bourgogne, C.; Donnio, B.; Guillon, D.; Imbert, D.; Bünzli, J.-C. G.; Pinto, A.; Jeannerat, D.; Piruet, C. J. Am. Chem. Soc. 2005, 127, 888-903. 